\title{
PROCESSO PARTICIPATIVO NO CONTROLE SOCIAL: UM ESTUDO DE CASO DO CONSELHO MUNICIPAL DE SAÚDE DE JUIZ DE FORA (MG) ${ }^{1}$
}

\author{
Fernanda Gabriela Gandra Pimenta Magalhães ${ }^{2}$ \\ Wescley Silva Xavier ${ }^{3}$
}

http://dx.doi.org/10.1590/1413-2311.233.87813

\begin{abstract}
RESUMO
Impulsionados pela mobilização da sociedade civil a partir década de 1980 e idealizados inicialmente pela mobilização de profissionais, em 1990 foram criados os conselhos municipais de saúde. Hoje, difundidos em todo Brasil, a existência desses confere caráter de controle social à gestão pública, permitindo ao povo participar na definição, execução e acompanhamento de políticas públicas. Nesse contexto, este estudo objetiva caracterizar o processo participativo no controle social, no âmbito do Conselho Municipal de Saúde de Juiz de Fora $(\mathrm{CMS} / \mathrm{JF})$. Metodologicamente o trabalho se caracteriza como essencialmente qualitativo, sendo utilizadas como abordagens de coleta dos dados entrevistas semiestruturadas, análise documental das atas das reuniões e observação não participante, todas analisadas à luz da Análise de Conteúdo. A partir das categorias processo de escuta e exercício do papel do conselheiro, os resultados sinalizam que os temas debatidos no conselho são amplos e diversos, sendo destacada também, a forte participação dos usuários. Não obstante esses aspectos positivos, pontos críticos foram encontrados, como tentativas de coerção, falta de debates profícuos, tempo escasso para discussões profundas e a existência de barreiras ao processo deliberativo e assimetrias discursivas.

\footnotetext{
${ }^{1}$ Recebido em 31/10/2018; aprovado em 03/04/2019.

${ }^{2}$ Universidade Federal de Viçosa - Departamento de Administração e Contabilidade e Programa de PósGraduação em Administração; Viçosa - MG (Brasil) - fernandagmagalhaes@gmail.com

3 Universidade Federal de Viçosa - Departamento de Administração e Contabilidade e Programa de PósGraduação em Administração; Viçosa - MG (Brasil) - wescleysxavier@yahoo.com.br
} 
Palavras-chave: Conselhos municipais de saúde. Participação social. Controle social. Processo participativo.

\title{
SOCIAL CONTROL IN PARTICIPATORY PROCESS: A CASE STUDY OF THE MUNICIPAL HEALTH COUNCIL IN JUIZ DE FORA (MG)
}

\begin{abstract}
Stimulated by the mobilization of civil society since the $80 \mathrm{~s}$ and first idealized by professionals, municipal health councils were created in Brazil in 1990. Present now in all over Brazil, its existence gives features of social control on the public management, allowing the citizens to participate of definition, execution and monitoring on public policies. In this context, this paper aims to characterize the participatory process in the social control of Municipal Health Council in Juiz de Fora (CMS/FJ). Methodologically this paper is essentially qualitative, in which the data were collected by semi structured interviews, documental analysis and non-participant observation. All these data had been analyzed by content analysis. Based on two categories - listening process and the role of counselor, the findings show that the debated topics in the health council are vast and diverse, as well as the participation of users is strong. Despite these positive findings, critical points have raised up, as attempts to coercion, lack of fruitful debate, scarce time for discussions in deep, existence of barriers to the deliberative process, and discursive asymmetry.
\end{abstract}

Keywords: Municipal health council. Social participation. Social control. Participatory process.

\section{EL PROCESO PARTICIPATIVO EN EL CONTROL SOCIAL: UN ESTUDIO DE CASO DEL CONSEJO MUNICIPAL DE SALUD DE JUIZ DE FORA (MG)}

\section{RESUMEN}

Estimulados por la movilización de la sociedad civil a partir de la década de 1980 e diseñado inicialmente por la movilización de profesionales, en 1990 se crearon los consejos municipales de salud. Hoy, difundidos en todo Brasil, la existencia de esos confiere carácter 
de control social a la gestión pública, permitiendo al pueblo participar en la definición, ejecución y acompañamiento de políticas públicas. En este contexto, este artículo busca caracterizar el proceso participativo en el control social, en el ámbito del Consejo Municipal de Salud de Juiz de Fora (CMS / JF). Metodológicamente el trabajo se caracteriza como esencialmente cualitativo, siendo utilizadas como abordajes de recolección de los datos entrevistas semiestructuradas, análisis documental de las actas de las reuniones y observación no participante, todas analizadas a la luz del Análisis de Contenido. A partir de las categorías proceso de escucha y ejercicio del papel del consejero, los resultados señalan que los temas debatidos en el consejo son amplios y diversos, siendo destacada, también la fuerte participación de los usuarios. A pesar de estos aspectos positivos, se encontraron puntos críticos, como intentos de coerción, falta de debates profundos, tiempo escaso para discusiones profundas y la existencia de barreras al proceso deliberativo y asimetrías discursivas.

Palabras clave: Consejos municipales de salud. Participación social. Control social; Proceso participativo.

\section{INTRODUÇÃO}

A mobilização e organização da sociedade civil brasileira, a partir do final da década de 1970 e início da década de 1980, com destaque entre outros, ao Movimento da Reforma Sanitária (MRS), deram sinais de uma sociedade civil com capacidade de organização e mobilização, algo não visto antes no cenário nacional (CORTES, 2002; COTTA et al., 2010; CRISTO, 2012; LAVALLE，2011; MIRANDA; GUIMARÃES， 2013;ROLIM; CRUZ; SAMPAIO, 2013 ).

O pioneirismo da saúde na militância por um sistema de melhor qualidade, equânime e participativo, sobretudo no MRS, faz com que a sociedade civil seja precursora em criar artifícios legais para incorporação dessa participação na gestão pública. Entre essas iniciativas está a instituição dos conselhos gestores nos níveis federal, estadual e municipal. A proposta com a criação desses espaços é que os cidadãos passem a incorporar o processo de tomadas de decisão na Administração Pública, de fiscalização e controle das ações e avaliação dos resultados alcançados pela ação governamental (CGU, 2012). 
A presença de cidadãos nesses conselhos confere caráter diferenciado à gestão pública e assume-se como controle social, que pode ser entendido como o processo pelo qual o povo participa na definição, execução e acompanhamento de políticas públicas, incorporado na Constituição Federal de 1988 por meio do princípio da participação, sendo concebido na política de saúde como a própria participação da comunidade (CORREIA, 2012; DUARTE; MACHADO, 2012; GURGEL; JUSTEN, 2013; SILVA et al., 2012; ). Assim, idealizados inicialmente pela mobilização de profissionais de saúde e de setores da sociedade civil, é com a Lei $n^{\circ} 8.142$ de 28 de dezembro de 1990 que são criados os conselhos municipais de saúde (CMS), instâncias de participação cívica na gestão do Sistema Único de Saúde (SUS) (VAN STRALEN et al., 2006). Em complemento, cabe destacar que o processo participativo não apenas pode ser imperativo no modelo de democracia contemporânea, como também pode influenciar a vida dos que dele participam (ROBERTS, 2004).

Importa salientar que partimos aqui da compreensão proposta por Cotta et al. (2011), de que o controle social é ao mesmo tempo um requisito e um instrumento indispensável para a construção do direito à saúde em uma sociedade democrática, sendo os conselhos de saúde uma inovação política, institucional e cultural para a consolidação do SUS. Nesse contexto, entendendo que são necessários estudos que se proponham a analisar a dinâmica de funcionamento dos CMS na elaboração de políticas públicas e no controle das ações exercidas. Com isso, este artigo objetiva caracterizar o processo participativo no controle social, no âmbito do Conselho Municipal de Saúde de Juiz de Fora (CMS/JF), em Minas Gerais.

Partimos do pressuposto que a análise do controle social passa pela participação, uma vez que, no caso brasileiro, é entendido como a própria participação cidadã na gestão pública, a qual se caracteriza como um mecanismo de controle das ações do Estado e de fortalecimento da cidadania (CGU, 2012). Dessa maneira, de forma particular visamos verificar como ocorre a participação dos conselheiros, como se dá a organização e participação dos segmentos e o processo de escuta, além de investigar o exercício do papel do conselheiro enquanto membro que participa da gestão pública ${ }^{4}$.

\footnotetext{
${ }^{4}$ Esse trabalho é parte da dissertação intitulada "Controle Social no Processo Participativo: um estudo no Conselho Municipal de Saúde de Juiz de Fora (MG), defendida no PPGAdm/UFV por Fernanda Gabriela Gandra Pimenta Magalhães. Agradecemos à Coordenação de Aperfeiçoamento de Pessoal de Nível Superior (CAPES) pela bolsa concedida.
}

REAd | Porto Alegre - Vol. 25 - No 1 - Janeiro / Abril 2019 - p. 179-212 


\section{CONSELHOS GESTORES DE POLÍTICAS PÚBLICAS}

O contexto democrático e de abertura à participação, exige além de novas relações, democráticas e dialógicas, entre sociedade e Estado, a construção de estruturas institucionais capazes de sustentá-la e o fortalecimento de espaços públicos não estatais (OLIVEIRA; PEREIR; OLIVEIRA, 2010). De acordo com Avritzer (2000), os conselhos gestores são apontados como atores-chave da democracia deliberativa no Brasil e desse processo em nível municipal.

Embora a experiência de conselhos tenha sido utilizada no Brasil pela primeira vez no Estado Novo (1937-1945) e posteriormente no governo militar instaurado a partir de 1964, com a redemocratização do país na década de 1980 forma-se uma nova concepção do papel desses órgãos e o movimento de criação dessa instância ganha força (BORBA, 2004; WENDHAUSEN; BARBOSA; BORBA, 2006). Assim, é possível afirmar que os conselhos gestores de políticas públicas como se conhece hoje foram concebidos a partir do fim da década de 1980 e início da década de 1990.

A criação desses conselhos tem como pano de fundo a mobilização social pela luta na busca de maior equidade e pela não marginalização (WENDHAUSEN; BARBOSA; BORBA, 2006). Shapiro (2002) destaca que a participação é fundamental para que se consiga, de maneira coletiva, reduzir as assimetrias existentes no campo político e econômico, sobretudo aqueles que possuem menos poder de influenciar decisões relevantes. Por consequência, a ausência de conselheiros que possam representar grupos historicamente marginalizados agrava o histórico quadro de elitismo no processo deliberativo (CHASUKWA, CHIWEZA; CHIKAPA-JAMALI, 2014).

Abers e Keck (2008) destacam que a proposta de conselhos gestores surgiu com o movimento de saúde, que propôs um programa concreto para novas instituições democráticas e a descentralização do sistema de saúde. Com base nas reivindicações por participação da sociedade nos processos de gestão pública e na definição constitucional relativa às mesmas, foram criados a partir de 1988 inúmeros conselhos gestores de políticas públicas, nos níveis municipal, estadual e federal (WENDHAUSEN; BARBOSA; BORBA, 2006).

Nascem como novos espaços de exercício da cidadania por meio do poder político, permitindo que a sociedade civil atue junto ao Estado nas decisões públicas, mediante um contexto democrático (SOUZA et al., 2012). Os conselhos brasileiros apresentam um formato peculiar, que aglutina representação de associações e de órgãos estatais, configuração essa originada de movimentos populares por um lado e burocratas reformistas por outro, que 
antecederam a criação dos mesmos (ABERS; KECK, 2008). Representam meios públicos de deliberação criados para promover a participação social, abarcando funções de tomadas de decisões sobre políticas públicas e regulação das ações do governo, cujo potencial reside na contribuição para democratização da gestão pública, ampliação da participação cívica, condução de políticas sociais, accountability e estreitamento das relações entre população e poder local (OLIVEIRA; PEREIRA; OLIVEIRA, 2010).

Constitui-se em arena para debate e tomada de decisão, fonte para a legitimação das decisões públicas e potenciais instrumentos de cobrança e de transparência nas decisões e ações do poder público (ABERS; KECK, 2008; GUIZARDI; PINHEIRO, 2006; KLEBA; COMERLATTO, 2011). Segundo Fuks et al. (2003), esses espaços constituem uma das principais experiências de democracia participativa no Brasil e estão presentes na maioria dos municípios brasileiros, abrangendo uma variedade de temas como saúde, educação e direitos dos idosos, representando uma conquista do ponto de vista da construção de uma instituição democrática. Atuam em parceria com o Poder Executivo na formulação de estratégias e no controle da execução da política pública, além da físcalização das contas públicas e deliberação sobre o relatório de gestão do governo (MARTINS; CKAGNAZAROFF; LAGE, 2012). Constituem-se em espaços não só de expressão de opiniões, mas também de ação, como forma de identificar demandas e interesses públicos, agindo para que esses entrem efetivamente na agenda pública (MARTINS; CKAGNAZAROFF; LAGE, 2012).

De acordo com a Controladoria Geral da União, os conselhos são instâncias de exercício da cidadania que abrem espaço para participação popular na gestão pública e têm fundamentalmente as seguintes funções: i) Função fiscalizadora: refere-se ao acompanhamento e o controle dos atos praticados pelos governantes; ii) Função mobilizadora: diz respeito ao estímulo à participação popular na gestão pública e às contribuições para a formulação e disseminação de estratégias de informação para a sociedade sobre as políticas públicas; iii) Função deliberativa: prerrogativa dos conselhos de decidir sobre as estratégias utilizadas nas políticas públicas de sua competência; iv) Função consultiva: relaciona-se à emissão de opiniões e sugestões sobre assuntos que lhes são correlatos (CGU, 2012).

Cabe notar que legalmente os conselhos de saúde possuem caráter deliberativo, isto é, suas decisões têm poder de interferir diretamente nas decisões governamentais (BRASIL, 1990; SIQUEIRA; COTTA; SOARES, 2015). Todavia, este caráter deliberativo é limitado pela necessidade de homologação governamental em relação a determinadas categorias de deliberação (SIQUEIRA; COTTA; SOARES, 2015). Sua capacidade de intensificar e 
institucionalizar o diálogo entre governo e sociedade como condição para uma alocação eficiente dos recursos públicos é o que o diferencia dos demais espaços democráticos (TATAGIBA, 2005).

Nesse sentido, além de representarem meios públicos de deliberação criados para promover a participação social, os conselhos gestores representam um meio de democratização das políticas sociais a partir do diálogo com o poder local (OLIVEIRA; PEREIRA; OLIVEIRA, 2010). De acordo com Goulart (2011) os conselhos gestores de políticas públicas representam, no Brasil, um importante instrumento para exercício do controle social, criados para participação e inclusão da sociedade civil. Conforme dito anteriormente, o campo que mais tem se destacado historicamente no incentivo à participação popular e criação de conselhos gestores é o setor de saúde, sobretudo, no que concerne à criação de leis que regulam e estimulam a criação de conselhos gestores de políticas públicas em saúde no nível municipal. A seção seguinte aborda os conselhos municipais de saúde, com destaque para a proposta de controle social incorporada pelos mesmos.

\section{O PROCESSO PARTICIPATIVO E A DINÂMICA DE FUNCIONAMENTO DO CONSELHO}

A análise do processo participativo e a respectiva dinâmica de funcionamento são importantes elementos de análise do controle social exercido no CMS. Envolve a análise da dinâmica de funcionamento com relação à participação e as deliberações do conselho, no sentido de identificar se essas caminham na direção do controle social. Entendemos que estes são critérios relevantes, uma vez que, a depender de como se dá esse processo, o controle social pode assumir diferentes formas.

O conceito de controle social que aqui se admite, incorpora em si a participação e deliberação como requisitos para seu exercício, de forma que o controle social é concebido na política de saúde brasileira como a própria participação da comunidade na definição desta política (CORREIA, 2012; SILVA et al., 2012). Assim, além de participar, cabe aos cidadãos no exercício do controle social, deliberar e decidir sobre os rumos das políticas públicas, podendo o próprio controle ser definido como um processo permanente de deliberação compartilhada entre sociedade e administração pública (GOULART, 2011).

Dessa forma, na análise dos CMS enquanto espaços de controle social torna-se importante verificar como se dão a participação e deliberação, uma vez que, conforme 
Oliveira, Pereira e Oliveira (2010) estes representam meios públicos de deliberação criados para promover a participação social.

Souza (2001) destaca que a participação pode ser entendida como uma forma de agregar os indivíduos da sociedade civil de maneira que estes participem na administração pública. Entendendo dessa forma, consideramos relevante compreender como ocorre a participação dos conselheiros no conselho e nas reuniões, bem como o modo que se dá a organização e participação dos segmentos. Além disso, é necessário compreender o exercício do papel do conselheiro enquanto membro que participa da gestão pública.

Não obstante ser a participação elemento intrínseco ao controle social é preciso demarcar o caráter performático de algumas instâncias. Nesses casos, os conselhos podem ser entendidos como dispositivos institucionais que buscam forçar a deliberação como um intermediário de regulação entre a intervenção excessiva e o conhecimento dos estabelecidos no conselho (SHAPIRO, 2002). Dessa forma, a possibilidade de significação do espaço como inclusivo ou apenas mantenedor do interesse de uma parcela envolvida faz com que tanto o caráter democrático como o de um instrumento que perpetua a desigualdade e a submissão se tornem possíveis (SALIBA et al., 2009).

Para análise da participação no contexto do conselho, são importantes as apreciações relativas à participação por segmento, o engajamento e o exercício do próprio papel de conselheiro. Duarte e Machado (2012) consideraram este um elemento importante na análise do controle social, utilizando como parte de sua investigação, a participação por segmentos no âmbito do conselho e a participação dos conselheiros nas reuniões. Zambon e Ogata (2013) também incorporam critérios de participação à análise do controle social, investigando como se dá o exercício do papel de conselheiro em termos de participação. Oliveira, Ianni e Dallari (2013) assinalaram em seu estudo que o controle social é no geral encarado como a própria participação por parte dos conselheiros.

Além de espaço de participação da comunidade na gestão do SUS, o conselho de saúde possui caráter deliberativo (BRASIL, 1990). Isso significa que, além de aberto à participação, o CMS possui atribuições deliberativas, isto é, tem a responsabilidade de discutir e decidir sobre as políticas de saúde a nível local (MARTINS, 2010). Martins (2010) ainda nota que este caráter deliberativo confere a ele maior respaldo no exercício de sua função de controle social. Portanto, este elemento não pode ser desconsiderado nesta análise. Rolim, Cruz e Sampaio (2013) assinalam a importância de que o controle social seja realmente deliberativo, além de autônomo, paritário e democrático. Van Stralen et al. (2006) incorporam a análise das deliberações do conselho em seu estudo sobre efetividade do 
controle social. Cristo (2012) utilizou como categorias para o controle social em saúde a análise da dinâmica das reuniões para as avaliações, análises e aprovação de planos, programas e projetos.

\section{CONTROLE DEMOCRÁTICO}

Entendemos que a análise aqui empreendida passa ainda pelo estudo da forma como esse é exercido e como os conselhos se consolidam como espaço de controle social, mediante existência de práticas democráticas efetivas. Essa análise remete à análise do controle democrático, isto é, identificar se no processo de controle social, as práticas democráticas são preservadas.

Torna-se importante a análise desse critério, uma vez que além da proposição dos conselhos serem a construção de espaços de controle democrático, a própria proposta de controle social visa, dentre outros propósitos, fortalecer este processo democrático (DIEGUES, 2013; ROLIM; CRUZ; SAMPAIO, 2013). Assim, o controle social exercido nos conselhos municipais de saúde, isto é, a perspectiva do controle social compartilhado entre a administração pública e a comunidade, tem suas bases nos valores democráticos (GOULART, 2011; MAGALHÃES; SOUZA, 2015).

Herian et al. (2012) destacam que a participação em processos deliberativos não apenas atribui status de justiça às deliberações, mas também permite que o conhecimento a respeito dos recursos públicos envolvidos na gestão pública crie um sentimento de justiça sobre os resultados da própria gestão.

Conforme Justino Filho (2007), para que o conselho cumpra seu papel de exercer o controle social é necessário, dentre outros requisitos, que se preserve uma estrutura de poder democrática e que hajam conselheiros qualificados técnica, institucional e politicamente neste processo. Diegues (2013) destaca para que o controle social seja efetivo é necessária a superação de certas limitações que impedem um exercício democrático deste controle. Notase, assim, que o desenvolvimento de práticas democráticas efetivas na sociedade é de extrema importância para o fortalecimento do controle social (COTTA et al., 2011; COTTA; CAZAL; MARTINS, 2010; MARENT; FORSTER; NOWAK, 2015).

Assim, consideramos que a presença de conselheiros qualificados de forma técnica, institucional e politicamente é um elemento importante para que o conselho consiga cumprir seu papel de controle social (JUSTINO FILHO, 2007). Além disso, Zambon e Ogata (2013) identificam o acesso a capacitações como um dos entraves para o exercício da função de 
conselheiro e como um desafio imposto para fortalecimento do controle social no conselho. Constitui-se este como um indicador de "práticas democráticas" no conselho, ao compreender conforme Wendhausen e Cardoso (2007) que é imprescindível que os conselheiros se apoderarem de conhecimentos para participar das discussões, como uma forma de resistência na articulação de rede, na busca de vencer as lutas pela autodeterminação e conquista efetiva da democracia e do controle social.

Desta maneira, na medida em que os conselheiros sejam qualificados (técnica, institucional e politicamente), caminha-se no sentido da igualdade participativa, isto é, da isonomia de atuação nos processos de tomada de decisão nas políticas públicas, uma vez que este processo implica em desenvolver nos conselheiros habilidades para lidar com o grupo e o desenvolvimento de capacidade de contra argumentação (WENDHAUSEN; CARDOSO, 2007). Todavia, é preciso destacar que esse processo é também influenciado por variáveis exógenas, sobretudo, a estrutura municipal, o contexto institucional e a capacidade de mobilidade social (SABIONI et al., 2016).

\section{CONSIDERAÇÕES METODOLÓGICAS}

O presente trabalho busca caracterizar o processo participativo no controle social, no âmbito do Conselho Municipal de Saúde de Juiz de Fora (CMS/JF). O percurso estabelecido é de ordem qualitativa, com base no caso do CMS/JF. Os dados foram coletados por meio de entrevistas semiestruturadas, observação participante e análise das atas. As entrevistas foram realizadas junto a 14 conselheiros (E1 a E14), sendo oito do segmento usuários, três do segmento profissionais de saúde, dois do segmento prestador e um do segmento governamental. Como forma de definição do número de sujeitos entrevistados, utilizou-se o processo de amostragem por saturação categórica, aquele no qual se interrompe o processamento de novas observações e o recrutamento de novos participantes na medida em que elementos novos não são mais depreendidos a partir do campo.

A respeito da ancoragem epistemológica do trabalho, é preciso deixar claro que o mesmo é atravessado por orientações multi-paradigmáticas, se aproximando do caráter dinâmico que Paula (2016) propõe ao desenvolver o círculo das matrizes epistêmicas. É predominante no trabalho elementos de uma matriz hermenêutica, em que são combinados o uso da lógica interpretativa e a preferência pelo interesse prático (PAULA, 2016). Todavia, o viés funcionalista contido no institucionalismo se faz presente, dada a possibilidade de combinação paradigmática (BURREL, 2007). 
Com relação aos documentos, foram analisadas atas das reuniões ordinárias e extraordinárias do Conselho Municipal de Saúde. Utilizamos como critério para seleção do período de análise documental a última gestão concluída, que compreende o período de outubro de 2013 a outubro de 2015, totalizando 38 atas nos dois anos estudados, sendo 33 reuniões ordinárias e cinco extraordinárias. Esta é considerada uma fonte de suma importância na análise do controle social, uma vez que "as atas constituem uma fonte que, ao lado das observações diretas das reuniões, permitem ao analista captar o 'conselho em ação', indo além, portanto, de uma análise estática” (PERISSINOTTO; FUKS; SOUZA, 2003, p. 84). Além disso, as atas das reuniões são importantes na análise do conselho por serem documentos que registram a fala e os discursos políticos produzidos pelos atores no processo deliberativo, e que permitem dessa forma analisar o processo argumentativo, central na teoria deliberativa (AVRITZER, 2009).

O terceiro recurso metodológico utilizado para coleta dos dados foi a observação não participante, durante as visitas feitas ao Conselho Municipal de Saúde nos meses de junho e julho de 2016, sendo quatro (4) as reuniões ordinárias observadas neste período. De acordo com Godoy (1995) a observação, ao lado da entrevista, constitui-se em uma técnica fundamental e tem um papel importante na realização de um estudo de caso. A utilização deste método, ao permitir uma observação das reuniões, da relação entre os conselheiros e de sua atuação formal e informal, auxiliou a atribuição de sentidos a certas informações obtidas na análise das entrevistas e na análise das atas (GURGEL; JUSTEN, 2013).

Todos os dados coletados foram analisados baseados na Análise de Conteúdo (AC). Segundo Bardin (1979), as técnicas pressupõem três fases: a primeira fase corresponde à fase de organização propriamente dita, que tem por objetivo tornar operacionais e sistematizar as ideias iniciais, de forma a conduzir a um esquema preciso do desenvolvimento das operações sucessivas, num plano de análise. Nessa fase procedemos a escolha dos documentos analisados, a formulação dos objetivos, bem como a elaboração de indicadores que fundamentaram a interpretação final; a segunda fase, de exploração do material, consiste em operações de codificação, decomposição e enumeração em função dos procedimentos realizados na primeira fase, de forma a realizar um aprofundamento no material reunido, orientando-o pelo referencial teórico, surgindo sínteses das ideias; e, a terceira fase, de análise propriamente dita, os "resultados brutos" foram tratados de forma a se tonarem significativos e válidos. Após o tratamento dos dados foram elencadas duas categorias como representativas do processo participativo, sendo estas o processo de escuta (MARQUES, 
2009) e o exercício do papel do conselheiro (SHIMIZU et al., 2013; ZAMBON; OGATA, 2013).

Como forma de analisar o conteúdo e de modo a dar suporte à condução deste trabalho, foi construído o Quadro 1, que alinha dimensões às categorias de análise e unidades de registro, embasamento teórico e aos procedimentos de coleta de dados adotados.

\section{Quadro 1 - Dimensões e categorias de análise}

\begin{tabular}{|c|l|l|c|}
\hline Categorias & Unidades de Registro & \multicolumn{1}{|c|}{ Base Teórica } & Coleta de dados \\
\hline \multirow{4}{*}{$\begin{array}{c}\text { Processo } \\
\text { participativo }\end{array}$} & $\begin{array}{c}\text { Participação por } \\
\text { segmento no âmbito do } \\
\text { conselho }\end{array}$ & $\begin{array}{l}\text { Duarte; Machado (2012) } \\
\text { Shimizu et al. (2013) } \\
\text { Goulart (2011) } \\
\text { Perissinotto; Fuks; Souza (2003) } \\
\text { Avritzer et al. (2009) Cunha (2009) }\end{array}$ & Atas \\
\cline { 2 - 4 } & Processo de escuta & Marques (2009) & Entrevista \\
\cline { 2 - 4 } & $\begin{array}{c}\text { O exercício do papel do do } \\
\text { conselheiro }\end{array}$ & $\begin{array}{l}\text { Zambon; Ogata (2013) } \\
\text { Souza et al. (2012) } \\
\text { Shimizu et al. (2013) } \\
\text { Duarte; Machado (2012) } \\
\text { Bispo Júnior; Sampaio (2008) }\end{array}$ & Entrevista \\
\cline { 2 - 4 } & & &
\end{tabular}

Fonte: elaborado pelos autores.

Importa notar que, conforme Silva, Gobbi e Simão (2005), considerando as expectativas teóricas, os elementos de conteúdo foram agrupados por parentesco de sentido e organizados sob as devidas categorias analíticas que são caracterizadas. Estas categorias podem ser apriorísticas, isto é, definidas previamente ou não apriorísticas, que emergem do contexto das respostas dos sujeitos da pesquisa (CAMPOS, 2004). Seguimos nesta pesquisa o modelo fechado, com categorias apriorísticas, no qual o pesquisador define a priori as categorias apoiadas sob um ponto de vista teórico que se submete à realidade (CAMPOS, 2004; SILVA; GOBBI; SIMÃO, 2005). Assim, neste modelo o pesquisador já possui categorias pré-definidas, de larga abrangência e que comportam subcategorias (CAMPOS, 2004).

Sobre o objeto de estudo, cabe destacar que o $\mathrm{CMS} / \mathrm{JF}$ é um órgão colegiado, deliberativo, normativo, permanente e fiscalizador do SUS, vinculado à Secretaria Municipal de Saúde, composto por 108 conselheiros, sendo 54 titulares e 54 suplentes. Foi criado pela Lei Orgânica do Município, instituído pela Lei $\mathrm{n}^{\mathrm{o}} 8.076$ de 11 de maio de 1992 e regulamentado por regimento interno revisto em 2012 (resolução CMS 370/2012), que regula 
as atividades e atribuições do CMS do município. Possui representação quadripartite, isto é, metade dos conselheiros representam os usuários dos serviços do SUS (o que corresponde a 27 membros titulares); e a outra metade é dividida entre representantes do governo, prestadores de serviço e profissionais de saúde, cada um com nove conselheiros titulares.

\section{CARACTERIZAÇÃO DO CONSELHO MUNICIPAL DE SAÚdE DE JUIZ DE FORA}

O Conselho Municipal de Saúde de Juiz de Fora é um órgão colegiado, deliberativo, normativo, permanente e fiscalizador do SUS, vinculado à Secretaria Municipal de Saúde, composto por 108 conselheiros, sendo 54 titulares e 54 suplentes. Foi criado pela Lei Orgânica do Município, instituído pela Lei no 8.076 de 11 de maio de 1992 e regulamentado por regimento interno revisto em 2012 (resolução CMS 370/2012), que regula as atividades e atribuições do Conselho Municipal de Saúde do município. Possui representação quadripartite, isto é, metade dos conselheiros representam os usuários dos serviços do SUS (o que corresponde a 27 membros titulares); e a outra metade é dividida entre representantes do governo, prestadores de serviço e profissionais de saúde, cada um com nove conselheiros titulares.

Juiz de Fora conta, além do conselho municipal, com conselhos locais e regionais de saúde. No total, são 12 conselhos regionais de saúde (um para cada região sanitária de saúde) e 62 conselhos locais de saúde, sendo 14 deles na zona rural. Conforme o Artigo $4^{\circ}$ do Regimento Interno, estes conselhos seguem processo eleitoral, sendo que sua composição obedece ao seguinte critério: 70\% Representantes dos Usuários, 20\% de Representantes dos Trabalhadores de Saúde e 10\% de Representantes do Governo.

O Quadro 2 apresenta as categorias representadas no conselho, importando notar que, conforme descrito, entre os prestadores de serviço somente o Hospital Universitário e a sociedade de Medicina e Cirurgia têm assento garantido. Além disso, com relação à representação dos usuários, entre os 27 representantes, 17 advêm dos conselhos regionais de saúde e os outros 10 representam outras instituições. Desses 10 assentos, somente a UNIJUF/União Juiz-forana - Sociedade Pró-Melhoramentos de Bairros e Distritos possuem lugar garantido, de acordo com a Lei 10.333 de 12/11/2002, sendo que as nove vagas restantes são disputadas em processo eleitoral, obedecendo aos critérios expostos no Quadro 2. 


\section{Quadro 2 - Composição do Conselho}

\begin{tabular}{|c|c|}
\hline Categoria & Composição \\
\hline \multirow{9}{*}{$\begin{array}{l}\text { Representantes } \\
\text { do governo }\end{array}$} & 01 representante da Secretaria de Planejamento e Desenvolvimento Econômico - SPDE \\
\hline & 01 representante da Cia de Saneamento Municipal - CESAMA \\
\hline & 01 representante da Secretaria de Educação - SE \\
\hline & 01 representante da Secretaria de Saúde - SS \\
\hline & 01 representante dos Cursos da área de Saúde da Universidade Federal de Juiz de Fora \\
\hline & 01 representante da Superintendência Regional de Saúde - SES-Mg/SRS-Juiz de Fora \\
\hline & 01 representante do Departamento Municipal de Limpeza Urbana - DEMLURB \\
\hline & 01 representante da HEMOMINAS \\
\hline & 01 representante da Fundação Hospitalar do Estado de Minas Gerais - FHEMIG \\
\hline \multirow{5}{*}{$\begin{array}{l}\text { Prestadores de } \\
\text { serviços }\end{array}$} & 01 representante do Hospital Universitário - HU \\
\hline & 03 representantes das Instituições de Saúde, sem fins lucrativos \\
\hline & 03 representantes das Instituições de Saúde, com fins lucrativos \\
\hline & $\begin{array}{l}01 \text { representante dos Sindicatos e Associações Profissionais vinculados ou não ao Sistema } \\
\text { único de Saúde SUS, que prestam serviços de saúde a seus filiados. }\end{array}$ \\
\hline & 01 representante da sociedade de Medicina e Cirurgia \\
\hline \multirow{10}{*}{$\begin{array}{l}\text { Profissionais } \\
\text { de saúde }\end{array}$} & $\begin{array}{l}01 \text { representante do Sindicato dos Trabalhadores, Funcionários e Servidores Municipais da } \\
\text { Administração Direta, Indireta, Fundações, Autarquias, Empresas Públicas e Associações } \\
\text { Civis da Prefeitura de Juiz de Fora - SINSERPU }\end{array}$ \\
\hline & 1 representante do Sindicato dos Trabalhadores \\
\hline & 2 Públicos Estaduais de Saúde - SIND-SAÚDE \\
\hline & 01 representante do Sindicato dos Servidores da Previdência Social - SINTSPREV \\
\hline & 01 representante do Sindicato dos Médicos \\
\hline & 01 representante do Sindicato dos Odontólogos \\
\hline & 01 representante do Sindicato dos Enfermeiros \\
\hline & $\begin{array}{l}01 \text { representante do Sindicato ou de órgão de fiscalização dos Profissionais de Serviço } \\
\text { Social }\end{array}$ \\
\hline & 01 representante do Sindicato dos Psicólogos \\
\hline & $\begin{array}{l}01 \text { representante do Sindicato dos Empregados em Estabelecimentos de Serviços de Saúde } \\
\text { de Juiz de Fora }\end{array}$ \\
\hline & 17 representantes dos conselhos regionais de saúde \\
\hline $\begin{array}{l}\text { Usuários do } \\
\text { SUS }\end{array}$ & $\begin{array}{l}10 \text { representantes das demais Instituições da Sociedade Civil Organizada (sendo } 02 \\
\text { representantes dos Trabalhadores, através de seus Sindicatos; } 02 \text { representantes das } \\
\text { Instituições organizadas sob interesses da sociedade em geral; } 02 \text { representantes das } \\
\text { Instituições organizadas sob interesses das crianças, adolescentes, mulheres e Idosos; } 02 \\
\text { representantes das Instituições dos usuários de serviços de saúde especializados e dos } \\
\text { segmentos; populacionais de maior risco sanitário; } 01 \text { representante das Instituições dos } \\
\text { seguimentos institucionalmente organizados sob outros interesses de proteção pública e de } \\
\text { bem estar social, cujas preocupações contemplam, direta ou indiretamente, as questões } \\
\text { sanitárias; } 01 \text { representante da UNIJUF/União Juizforana - Sociedade Pró-Melhoramentos } \\
\text { de Bairros e Distritos). }\end{array}$ \\
\hline
\end{tabular}

Fonte: elaborado pelos autores com base no Regimento Interno do Conselho Municipal de Saúde de Juiz de Fora (2012).

Essa composição do conselho, que abrange um leque significativo de entidades, aponta um significativo grau de representatividade, uma vez que, como apontam Machado, Batista e Kornin (2004) um conselho se torna representativo na medida em que agrega distintos segmentos da sociedade civil e, portanto, diferentes entidades a serem representadas. 
Cada gestão do conselho compreende o período de dois anos, sendo permitida uma recondução. As eleições acontecem no geral no mês de setembro dos anos ímpares, sendo outubro considerado um período de transição e novembro o início da nova gestão.

O regimento interno do conselho apresenta em seu Artigo $2^{\circ}$ a finalidade de atuar na formulação e no controle da execução da política municipal de saúde, inclusive nos aspectos econômicos, financeiros, estratégias e promoção do processo de Controle Social em toda a sua amplitude, no âmbito do setor público e privado no município de Juiz de Fora. Importa notar que o conselho ainda segue as determinações das resoluções no 33 de 1992 e no 333 de 2003 do Conselho Nacional de Saúde, revogadas pela resolução nº 453 de 2012.

De acordo com o Ministério da Saúde, a estrutura de funcionamento é importante para que se garanta a funcionalidade do Conselho e de modo a evitar que ocorram relações de poder entre os próprios conselheiros e que se instaurem rotinas burocráticas prejudiciais (BRASIL, 2013b). De acordo como o regimento interno, o Conselho Municipal de Saúde de Juiz de Fora é constituído por:

- Plenário - é o fórum de deliberação do conselho e deve reunir-se, no mínimo, a cada mês e extraordinariamente quando necessário, sendo suas reuniões abertas ao público (BRASIL, 2013b). O Conselho Municipal de Saúde de Juiz de Fora realiza mensalmente duas reuniões ordinárias, na quarta quarta-feira e na quinta-feira de cada mês e, além disso, pode reunir-se extraordinariamente quando convocado pela mesa diretora do conselho ou pela maioria simples de seus membros.

- Mesa Diretora - de acordo com o Ministério da Saúde deve ser composta por conselheiros titulares, eleitos pelo Plenário, inclusive o presidente é responsável por conduzir os processos administrativos e políticos a serem deliberados pelo Plenário e promover articulações políticas internas e externas, garantindo a intersetorialidade do controle social (BRASIL, 2013b). Quanto à composição da Mesa Diretora, o regimento interno do conselho de Juiz de Fora define que esta deverá ser composta por conselheiros indicados pelos segmentos, observando-se a paridade representativa, isto é, um representante do Governo, um representante dos Prestadores de Serviço, um representante dos Profissionais de Saúde e três representantes do Segmento dos Usuários, além do representante da Secretaria Executiva e da Ouvidoria de Saúde.

- Comissão de Recursos da Saúde - de acordo com o regimento interno, esta é a comissão constituída para apreciações acerca dos recursos destinados à saúde. 
- Comissões Temáticas - de acordo com o Ministério da Saúde as comissões são responsáveis por prestarem assessoria ao Plenário, podendo possuir caráter temporário ou permanente (BRASIL, 2013b).

- Secretaria Executiva - deve fornecer o suporte técnico-administrativo ao Conselho de Saúde, sendo subordinada ao Plenário (BRASIL, 2013b). O regimento interno postula que o cargo deverá ser ocupado preferencialmente por representante do segmento dos usuários. Além disso, o mesmo regimento define que o mandato para a secretaria executiva será de dois anos permitida uma e somente uma recondução, por mais um mandato de dois anos. O Na gestão identificada nessa pesquisa o Secretário Executivo do conselho está no cargo há 16 anos (desde 2000).

- Ouvidoria Municipal de Saúde - de acordo com o regimento interno do conselho este é o órgão destinado à fiscalização e intermediação entre o gestor municipal de saúde e os usuários do SUS, os prestadores de serviços, públicos ou privados, os servidores públicos do setor. Ainda de acordo com o regimento, o cargo deve ser ocupado, preferencialmente por um usuário, sendo que o ouvidor será eleito pelo plenário para um mandato de dois anos.

\section{APRESENTAÇÃO E DISCUSSÃO DOS RESULTADOS}

Consideramos que a deliberação é uma atividade discursiva na qual se estabelece um diálogo entre diferentes atores, constituindo-se, portanto, em um processo social de comunicação no qual os indivíduos apresentam seus pontos de vista e perspectivas diante dos pares, interpelando-os e demandando-lhes a validação de seus argumentos após discussão centrada no respeito recíproco (MARQUES, 2009).

Entendendo o processo deliberativo conforme exposto acima e compreendendo que este prescinde de uma troca de razões entre indivíduos, intercompreensão e interpelação recíproca (MARQUES, 2009), buscamos analisar a “escuta” dentro do conselho, sendo esta a parte deste processo responsável pela troca de razões mútuas, sendo essas trocas mais relevantes que a mera vocalização.

Verificamos que onze (11) entrevistados compartilham a percepção de serem escutados pelos pares em seu processo de fala. Sobre o processo de escuta no conselho, os entrevistados apontam que há uma de troca de razões através da escuta mútua e não apenas um processo de falas soltas. Além disso, apontam para importância do conselho enquanto 
articulador entre sociedade-Estado, sendo possível compreendê-lo como um espaço no qual diferentes demandas são ouvidas e diferentes argumentos são trocados.

Entretanto, um dos entrevistados destaca que este é um fator que depende da discussão em pauta, de forma que quanto mais polêmico for o tema, menor tende a ser este nível de escuta:

Depende do momento, do calor da discussão. Tem determinados temas que são polêmicos, e as vezes é... A gente tem que pedir por uma questão de ordem, tem que esperar um pouco né, mas de um modo geral a gente acaba sendo ouvido e ouvindo também. Só que as vezes descontrola um pouco né. Discussão, muita gente, acaba desviando um pouco o foco (E14, Segmento Usuário).

A fala de E14 sinaliza um fato interessante, quando condiciona a existência da troca de razões apenas à convergência de interesses. Todavia, quando os temas são polêmicos e quando há divergência de posicionamentos, este processo torna-se dificultado. É esse o ponto crítico, tornando o processo de escuta mais essencial diante de posicionamentos divergentes, configurando a troca de razões. Ao contrário disso, se essa troca de razões só acontece quando os posicionamentos são semelhantes, é como se o processo discursivo ficasse abalado, mitigando o potencial de superação do quadro elitista que historicamente se faz presente nos processos deliberativos destacados por Chasukwa, Chiweza e Chikapa-Jamali (2014).

Foi destacada ainda a utilização de outras formas de se fazer ouvir dentro do conselho e persuadir os pares, principalmente através da forma escrita. $\mathrm{O}$ fato de valerem-se de outras formas para se fazer ouvir no conselho, ou como relata o entrevistado, de convencer os demais com base em seu interesse, indica que as formas de persuasão extrapolam as falas e que há uma articulação informal concorrente a estas, conforme a fala a seguir:

[...] E você tem pouco tempo pra poder falar, por que são três minutos pra falar, e nem sempre em três minutos você pode expor as coisas. Por que quando entra, por exemplo, pauta em cima da hora, alguém presta atenção. Alguém presta atenção. E, aí a gente tem uma forma de convencimento e ai a gente trabalha, quando a gente quer trabalhar o nosso interesse, ai a gente não trabalha só na fala lá no microfone. A gente trabalha de forma, assim de folheto, passando para as pessoas, informação por escrito, de forma escrita. Né, a gente explica, as pessoas tomam conhecimento por que você quer ou o que 
que você é contra. Ou você é contra ou a favor (E5, Segmento Profissionais de Saúde).

Não obstante as estratégias de persuasão, comuns aos processos deliberativos, observou-se que a legitimidade da deliberação é atravessada por relações assimétricas de poder entre as partes, desatacadas por Shapiro (2002) e Saliba et al. (2009). Essa assimetria, com seus elementos de ordem simbólica embutidos, provoca intimidação em razão de uma barreira formada pelo poder manifestado pelo uso da linguagem.

[...] Usuário é na minha concepção o que precisava trabalhar mais, pra poder ajudar ele a se definir e tecnicamente se estabelecer, por que...Quando se chega lá, quem participa das comissões as vezes fica assim intimidado em pedir esclarecimentos [...] Acho que fica assim acanhado pra poder [...] Bom, fala, os usuários fala bastante né... Porém, ele não assim muito objetivo nas suas colocações. Ai você vem, aí você vem com, com o governo, que tem a sua fala mais objetiva, mais bonita. Quando fala bonito, impressiona, quem não sabe falar. É... Falou bonito, agradou. Falou feio, não agradou, $e$ não convenceu, não esclareceu. Por que você tem pessoas muito bem intencionadas do usuário que não conseguem externar ali, e quando pega o microfone, ele fica nervoso e tímido, e falar errado. No caso de alguns. Tem uns que não liga não. Mas a maioria não pega. [...] Quem fala bem também tem seu tom político, né. Quem fala bem o próprio governo seleciona. 'Esse eu preciso agradar, para eu poder ter maioria absoluta'. Até por que, quem governa, precisa governar com a maioria absoluta para poder fazer valer interesses coletivos, pessoal etc. (E5, Segmento Profissionais de Saúde).

Este depoimento coincide com o que aponta Marques (2009, p. 21), sobre a necessidade de se "verificar na prática discursiva dos indivíduos como as opressões simbólicas, as desigualdades econômicas, a invisibilidade social e a falta de habilidade para usar racionalmente a linguagem criam barreiras ao engajamento na deliberação". E5, apesar de não identificar qual é o segmento com maior capacidade de vocalização, discorre sobre assimetrias discursivas, o que leva a afirmar, baseando-nos nas palavras de Marques (2009), que no CMS/JF a linguagem tem criado barreiras ao engajamento na deliberação.

Outra categoria de grande relevância para compreensão do processo participativo é o papel do conselheiro, que nos permite identificar a avaliação que os mesmos fazem da 
própria participação e de seus pares, cuja importância se baseia na necessidade de construir uma imagem desses atores que compõem o conselho, entendendo-os como os protagonistas do controle social (JUSTINO FILHO, 2007).

No geral, os entrevistados demonstraram empolgação com a função de conselheiro e orgulho em exercê-la, denotando a compreensão da importância tanto do espaço participativo quanto do próprio papel enquanto ator do controle social. A maioria dos conselheiros participa efetivamente, seja através das falas ou de trabalhos no conselho, mostrando-se inseridos no processo participativo.

Não obstante o caráter participativo, alguns pontos dissonantes foram encontrados, como tentativas de obstrução a determinadas falas de conselheiros que não se envolvem com questões político-partidárias. O depoimento de E1 indica que no momento de participação, há um processo de inibição ou constrangimento das pessoas que deixam de agir em prol de interesses particulares para agirem, conforme reza a finalidade do conselho, em nome da sociedade e de interesses coletivos:

[...] Eles ficam num desacordo de que não concordam comigo, por que eu não faço parte de política. [...] Esses emprego de contrato aí [...] (E1, Segmento Usuário).

Este depoimento endossa que a atuação dos conselheiros é passível de influências, destacando- se as questões político-partidárias e a atuação de grupos políticos, sobretudo, valendo-se da utilização de cargos públicos. Nelson, Gabris e Davis (2011) destacam que os interesses particulares manifestos no processo deliberativo estão diretamente relacionados à falta de efetividade dos conselhos, sendo mais agudo na medida em que as assimetrias de poderes entre as partes deflagram constrangimento como os supracitados.

A respeito do partidarismo presente no conselho, os achados vão ao encontro do que assevera Cornwall (2008), para quem a afiliação partidária dos conselheiros pode impactar significativamente a dinâmica da esfera participativa. Especificamente no caso do Brasil, Cornwall (2008) destaca ser esse partidarismo o "elefante" na sala dos processos deliberativos, algo também presente nos achados de Baocchi (2001), ao pesquisar aspectos do orçamento participativo em Porto Alegre/RS.

Os demais entrevistados se dizem menos participativos, sendo que três (3) deles atribuem este fato à recente inserção no conselho, revelando-nos que há de alguma forma, uma ligação entre uma atuação efetiva e tempo de participação. Estas falas ressaltam ao menos dois aspectos. Por um lado, sugere a necessidade natural dos conselheiros de se familiarizarem com as discussões, aprenderem os códigos e sentirem-se inseridos no 
conselho. Ao entrar num novo meio, seria necessário assimilar sua cultura, bem como as regras de conduta e os valores deste ambiente onde se inseriu. Esta é uma característica própria do momento de adaptação pelo qual passam os novos conselheiros e que é comum as fases de adaptação a novos espaços.

Por outro lado, pode indicar que há certa resistência a esses novos entrantes e em fazêlos sentir incluídos, sugerindo a possibilidade de um processo de inibição dos membros novatos, como se os conselheiros mais antigos se fechassem à discussão, gerando um processo de intimidação de novos entrantes no processo discursivo. Todavia, apesar de considerar natural a necessidade dos conselheiros em se familiarizarem com as discussões, as falas apontam ainda que por estarem há pouco tempo no conselho, sentem necessidade de adquirir maior conhecimento, quando relatam que querem estudar e conhecer mais (E4, Segmento Usuário), que estão "numa fase de observação, de levantamento de dados" (E7, Segmento Profissionais de Saúde) e que este é "um serviço muito complexo, abrange muita muitas leis, muitas medidas, resoluções que são alteradas constantemente" (E14, Segmento Usuário).

Outros dois entrevistados que alegam ter uma participação intermediária justificam suas posturas com argumentos que nos remetem a uma participação protocolar, quando afirmam preferir outro tipo de participação. Enquanto o depoimento de E10 atribui valores de certo ou errado e não dá valor à capacidade argumentativa exercida na plenária, o depoimento de E12 indica um afastamento da participação:

60\%. [...] Eu sou mais é de escrever, eu gosto mais de pedir por escrito. O protocolo e peço a resposta, do que ir na plenária e falar. Por escrito para mim é o que vale. (E10, Segmento Usuário).

[...] Eu procuro mais ouvir, é... aquilo que nós temos ali é... pessoas realmente é.. atuantes no conselho, que são pessoas as vezes, $o$ pessoal, um aposentado, que ele é talvez um usuário, ele fica mais ali por conta da comunidade ali, tá ali, participa mais (E12, Segmento Prestadores de Serviço).

Chama-nos especialmente atenção o depoimento de E12, que indica que o entrevistado parece se eximir de participar mais ativamente com base na alegação de que há outras pessoas mais atuantes que deveriam fazer isto. O conselheiro cita ainda o exemplo de pessoas aposentadas, sugerindo que por terem mais tempo livre, estas deveriam participar mais. Há uma contradição importante nesta fala. Por um lado, E12 é conselheiro, e por consequência, responsável pelo elo entre o conselho e coletividade, devendo representar seu 
segmento e manifestar as ideias e as demandas do grupo que ele representa, além de articular os interesses do conjunto dos usuários (BRASIL, 2013). Por outro lado, se exime deste papel alegando que o reserva para quem participa mais e está mais perto da comunidade. Indo além, este depoimento se torna ainda mais significativo quando verificamos que esta fala parte de um representante do segmento dos Prestadores de Serviço. Ao estabelecermos um paralelo ao que constatamos anteriormente, reforçamos a hipótese de que há uma representação proforma neste segmento, reduzida à ocupação de um espaço.

Após realizarem autoavaliação, os entrevistados discorreram a respeito da atuação de seus pares e do conjunto dos conselheiros. A participação dos conselheiros foi compreendida por nove entrevistados, apontando que eles participam das reuniões e discussões, agindo de forma otimista e com interesse em participar.

Corroborando com Duarte e Machado (2012), que sinalizam a capacidade e oportunidade de compreensão dos conselheiros como um fator determinante para efetiva participação, E7 destaca que, embora a participação seja satisfatória, a falta de entendimento sobre o próprio papel tende a prejudicar essa participação, dado que ao não compreenderem a dimensão do seu próprio papel, o processo argumentativo tende a ser prejudicado. Ademais, essa lacuna pode contribuir para a caracterização do conselho enquanto dispositivo institucional (SHAPIRO, 2002).

Foi destacada também a limitação socioeconômica como determinante do processo participativo, uma vez que tais dificuldades são impostas a parte da sociedade, que mesmo assim persiste em participar. O mesmo depoente destacou também a sua preocupação com relação à ausência de jovens participando deste espaço:

Eles são bastante participativos né. É claro que eles têm limitações, né, [...] infelizmente o acesso a determinadas coisas é negado à maioria da população. E são justamente essas pessoas que nos representam. Então eles têm suas limitações, têm suas dificuldades, tem as suas lutas diárias, mas são pessoas assim, que procuram estar atuantes, participativas dentro daquilo que ele se propõe. Muitos vêm isso aqui como uma vaidade pessoal, o que eu não acho que seja negativo, a partir do momento que você se compromete e atua. Agora, eu percebo também por outro lado que falta juventude. É... um número de pessoas mais jovens participando é pequeno. E isso me preocupa com relação ao futuro (E14, Segmento Usuário). 
Esta constatação vai ao encontro do que destaca Justino Filho (2007), que uma cultura cívica ainda tímida e desfavorecida por condições socioeconômicas, é um dos principais obstáculos ao bom "desempenho institucional" dos conselhos. Uma vez mais valemo-nos das palavras de Marques (2009), quando afirma que as desigualdades econômicas e a invisibilidade social podem criar barreiras ao engajamento na deliberação. A autora ressalta que os constrangimentos impostos por relações sociais e econômicas desequilibradas é um dos fatores que afetam o desenvolvimento de processos comunicacionais ligados à troca argumentativa e à orientação dos sujeitos em direção ao mútuo entendimento (MARQUES, 2009).

Além disso, o entrevistado ainda destaca que, apesar dos conselheiros terem interesse em participar e saberem da importância que têm, é preocupante a falta de engajamento da sociedade, já que boa parte dos cidadãos não se interessa em ocupar estes espaços:

[...] A minha grande preocupação, volto a dizer é com os que virão amanhã, por que eu não tenho percebido um interesse da sociedade em abraçar esses movimentos como ocorria no passado (E14, Segmento Usuário).

Foi destacada também a busca ativa dos conselheiros e o interesse desses em participar para além das reuniões. Enquanto membro representante do governo e tendo participado de diversos outros conselhos, E2 estabelece uma base comparativa e considera o $\mathrm{CMS} / \mathrm{JF}$ como o mais atuante entre os que conhece:

Ativamente! Todos eles me procuram... [...] Eles sempre estão procurando. [...] Me ligam, a gente atende todos, marca uma reunião junto com a gente que a gente atende todos. Seja da zona rural. [...] Além da reunião, sim. É muito atuante aqui mesmo o conselho. Eu nunca... De todas as cidades que eu trabalhei, que eu morei, eu nunca vi um conselho tão atuante igual aqui em Juiz de Fora (E2, Segmento Governo).

Em contrapartida aos pontos de vista apresentados até aqui, cinco (5) entrevistados julgam a participação como insuficiente ou razoável, dentre os quais se destaca o depoimento de E3, que contrasta a fala de E2 e avalia que os conselheiros são atuantes apenas no momento de reuniões da plenária, passando por dificuldades de participação, por exemplo, nas comissões:

São, são, são atuantes. [...] Olha só: são atuantes neste momento, de plenário. Você vê que é um Conselho Municipal de Saúde que você 
pôde observar que o plenário ontem estava cheio, mesmo a gente mudando a pauta, por que não era aquela pauta. [...] Nas comissões nós estamos com algumas dificuldades, por que às vezes não interessa muito para as pessoas e tal (E3, Segmento Usuário).

Entre aqueles que consideram que a participação é tímida, destacamos E13, que reforça a restrição da vocalização a um número limitado de sujeitos, e a fala de E1, que reitera que há casos em que a participação ocorre apenas por interesse político:

É o que eu te falei, todos são 54, mas nem todos falam. Desses 54, no máximo uns 15 é que falam, o resto apenas apoia ou não e vota (E13, Segmento Profissionais de Saúde).

Muitos estão por interesse político. Político põe antes aqui... [...] Não pode prevalecer não. Por que eu falo com eles: não, vocês estão errados... 'Ah não, mas se nós não fizer isso nós não arruma nada lá no bairro'... 'Ah, arruma, arruma sim...' (E1, Segmento Usuário).

$\mathrm{O}$ depoimento de E13 corrobora o número restrito de conselheiros vocalizantes. $\mathrm{O}$ entrevistado chama a atenção ao fato que poucos são os conselheiros que participam do processo discursivo, sendo massiva a participação apenas nas votações. Esse dado assinala que boa parte dos conselheiros é omissa enquanto representante dos interesses coletivos, eximindo-se de sua responsabilidade pela discussão, acompanhamento, deliberação, avaliação e fiscalização da implementação da política de saúde. E1 percebe que há conselheiros motivados por interesses políticos, apesar de assinalar que estes interesses não podem e não prevalecem no conselho, posto que há uma cobrança dos próprios conselheiros neste sentido, de atenção e vigilância pelo interesse coletivo.

Chamou atenção ainda a fala de E3, que assevera sobre o interesse dos conselheiros em participar e o reconhecimento da importância deste papel. Conforme o trecho abaixo, segundo E3, no geral os conselheiros inseridos há mais tempo no conselho têm consciência sobre o seu papel e importância, porém foi incisivo ao apontar a falta de interesse por parte do segmento governamental, inclusive no que diz respeito ao comparecimento nas reuniões:

Aqueles que tão mais, mais, mais na estrada, sabem a importância que tem. Os mais novatos vão aprender. Mas eles têm consciência do fato. [...] Sabe da importância que tem. O próprio conselho sabe da importância dele no contexto. [...] Não vou dizer pra você a maioria.. Às vezes... Vamos dizer que 95\% tem interesse. 5\% estão ali por um cumprimento de dever de ofício. Não vamos... Mas posso listar pra 
você o segmento governamental. Posso mostrar para você a lista de presença, as ausências. Não tem interesse... E eles deveriam ter mais interesse para estar aqui falando pelo governo [...] (E3, Segmento Usuário).

Esta fala reforça o processo de intimidação a membros novatos, ao apontar que enquanto os conselheiros mais antigos têm interesse em participar e sabem da importância, os novatos aprenderão com o passar do tempo. Além disso, esse discurso assinala que a maioria dos conselheiros realmente tem interesse em participar, mas que há um grupo (possivelmente o segmento governamental) que está lá apenas para cumprir algum dever de ofício, o que reforça nossa tese de que há uma representação apenas formal. A fala de E4 também ressalta esta participação proforma, quando aponta a possibilidade de que haja alguns conselheiros que não estejam comprometidos em participar:

Pois é, é isso que eu te falo, eu acho que alguns estão por estar né.

Por que é... Se tem um problema lá na sua área, eles não chegam aqui e expõe, entendeu? Então se eles não expõem, fica difícil (E4, Segmento Usuário).

Além de chamar a atenção para representação protocolar, E4 nos retoma a problemática da vocalização, apontando que alguns conselheiros não expõem o que está acontecendo, reforça o argumento de que as falas concentradas em poucos são problemáticas e faz com que apenas alguns representantes sejam de fato articuladores da voz da população.

O apontamento de E5 sinaliza que, mais do que apenas comportamentos motivados por posições políticas, muitas vezes os conselheiros sequer compreendem a importância de seus papeis e que por esta razão se deixam levar por interesses paralelos. De acordo com E5, a representação no conselho, nesse caso, se caracteriza por ser uma extensão do legislativo municipal, na medida em que conselheiros estejam submetidos aos interesses de vereadores.

[...] Eu acho que eles não percebem que aquilo é uma coisa muito importante. Que por que muitas das vezes o conselheiro ele vem a ser conselheiro por influência política também. É um vereador que quer que ele seja conselheiro, quer que ele esteja inserido no meio, participação nos movimentos sociais, ele traz visibilidade. Tanto isso quanto a opinião de parlamentar. E aí, mas também tem as pessoas que estão realmente comprometidas com aquilo, com a assistência, com o bem-estar da sociedade no geral. A maioria aí eu creio que esteja comprometida. Não sei se ela está tão esclarecida assim, sabe 
tanto da importância dele. Por que acho que nós também não temos muito como formar politicamente, esses cursos acho que seria importante né (E5, Segmento Profissionais de Saúde).

Esta fala indica tentativas do poder público em manipular ou ocupar espaços reservados à participação popular, o que faz com que os assentos sejam ocupados por pessoas mais comprometidas com interesses políticos do que com o interesse coletivo, mais uma vez sob o pretexto de participação social.

Ainda a respeito do papel de conselheiro, E7 salienta que embora saibam da importância do seu papel, há certa vaidade em participar do conselho, advinda da própria função do conselheiro que recebe alto grau de importância ao ter o poder de participar e decidir sobre as políticas públicas.

Eu acho que alguns têm consciência sim, da importância de participar. Mas há uma certa vaidade em participar, entendeu, do conselho. Não sei até que ponto isso atrapalha, ou não. Mas algumas pessoas você vê que é uma vaidade. Mas não que eles não trabalhem, entendeu? Não que eles não façam alguma coisa. É um orgulho pra eles participar. E eu acho isso até bacana, sabe. Por que as vezes, eles não têm a oportunidade, igual você estudou, igual eu estudei, né, e a gente vai estar em lugares que a gente escolhe $e$, as vezes tem muita gente aqui que não teve oportunidade. Então isso aqui é um, de certa forma, é um... né, você tá decidindo certas coisas que são importantes pra sociedade, né, pra eles, pro usuário, pra outros amigos, pra outros colegas. Então eu acho que isso é importante, sim né (E7, Segmento Profissionais de Saúde).

Com base nos fragmentos apresentados nessa análise, podemos afirmar que embora seja unânime o entusiasmo dos conselheiros com relação à participação, o processo deliberativo não é mola propulsora da ocupação dos espaços, na medida em que alguns se disseram mais envolvidos com as questões e debates do conselho, enquanto outros se consideram menos implicados nesse processo. Pelos discursos entusiastas, notamos que os conselheiros entendem que é importante desempenhar esse papel, devido a possibilidade de lutar por melhorias que irão beneficiar a sociedade, além de ser uma maneira de adquirir conhecimentos e tornar-se um sujeito ativo nas decisões das políticas de saúde do município. É necessário destacar que embora compreendam a importância em participar, há, no entanto, membros que se mostram ainda pouco envolvidos. Em complemento, as análises aqui dispostas 
indicam possíveis entraves ao exercício do papel do conselheiro, tais como falta de entendimento sobre o próprio papel, condições socioeconômicas dos conselheiros, interesses políticos e falta de comprometimento.

Para além do próprio processo participativo, é relevante destacar o uso do espaço participativo para legitimar proposições do poder público municipal, bem como o impacto dos diferentes lugares de fala na legitimidade do que é vocalizado. Com relação ao papel propositivo, os entrevistados apontam que o conselho atua na formulação de políticas de saúde, ao reconhecerem que exerce influência sobre o processo de concepção dessas. Indicam assim que o Conselho Municipal de Saúde de Juiz de Fora tem cumprido parte do seu papel previsto na Lei $\mathrm{n}^{\circ} 8.142$, que definiu que o conselho deve atuar na formulação de estratégias das políticas de saúde e, mais do que isso, este se consolida como um "arranjo de governança na formulação de políticas públicas” (ABERS; KECK, 2008, p. 100).

Embora tenha sido quase unânime entre os entrevistados a percepção de que o conselho tem proposto ações para saúde, o representante do governo considera que os conselhos desta área não propõem, mas apenas avalizam e sugerem melhorias nas propostas trazidas pelo governo:

Geralmente nós levamos as demandas e eles geralmente analisam as demandas e nos passam: 'olha, é, concordamos, mas a gente acha que assim seria melhor'. é... Eles propõem algumas melhorias nas nossas propostas. Geralmente eles não trazem assim... Geralmente eles recebem a demanda, analisam e dão a opinião deles. O que eles acham que pode otimiza (E2, Segmento Governo).

Chama atenção o fato de ser o representante do governo quem sinaliza não haver proposições do conselho, o que reforça a hipótese de pré-formatação das discussões, já demarcadas como entrave à consolidação de espaços democráticos por Shapiro (2002), Sablita et al. (2009), Nelson, Gabris e Davis (2011), dentre outros. A partir do momento em que aquele responsável por representar os interesses da gestão pública municipal afirma que é o governo quem leva as demandas e o conselho apenas analisa e opina sobre as mesmas, assume-se que as questões partem de "cima para baixo" e não "de baixo para cima". Assim, podemos afirmar que ao invés de a comunidade usar o conselho para levar suas demandas, é o governo quem usa o conselho como forma de validar suas decisões, o que caracteriza um ponto crítico nesse processo.

Diante dos apontamentos quanto ao caráter proforma do conselho, torna-se ainda mais urgente o acompanhamento das ações por parte da sociedade civil. Dessa forma, o fato de o 
conselho ser reconhecido por atuar na formulação de políticas públicas, nos leva a acreditar que essas políticas podem tornar-se "mais inclusivas e mais representativas de interesses sociais mais amplos" (ABERS; KECK, 2008, p. 103), isto por incorporar em sua composição membros usuários do SUS, que podem usar destes espaços para levar suas demandas e fazêlas se transformar em políticas voltadas à resolução destes problemas. Todavia, conforme relata um dos entrevistados, para que essas políticas sejam mais inclusivas e representativas de interesses sociais mais amplos, é necessário que haja um maior engajamento da sociedade, como condição para que o conselho tenha voz ativa, no sentido de ocupar este espaço e conseguir fazer com que, cada vez mais, as ações sejam pensadas e formuladas em conjunto e direcionadas às demandas latentes:

Na medida em que a sociedade apoiar sim. Agora, quanto menos interesse houver, menos voz a gente vai ter [...] na sociedade tudo é movido pelo, pelo eco da voz né. Eu não vou conseguir sensibilizar um prefeito que fica no último andar de um prédio se ele não me escutar. Então é preciso que mais pessoas se unam à minha voz pra que ela ecoe tão alto que chegue aos ouvidos dele. Por que ele não vai descer pra me ouvir. [...] Então, é, eu acredito que na medida em que, é, a população se mobilizar e apoiar as decisões do conselho, a gente vai ter mais espaço (E14, Segmento Usuário).

Este depoimento reitera a importância de que a sociedade se aproprie deste espaço, entendendo-o como forma legalmente instituída de intervir nas decisões públicas no sentido de direcioná-las ao interesse da comunidade. Conforme trecho supracitado, a importância em mobilizar-se e ocupá-lo se justifica por ser esta a forma que os cidadãos e usuários do SUS têm para unir-se e fazer-se ouvir, levando as demandas e fazendo com que elas cheguem até as autoridades responsáveis pela execução dessas ações. $\mathrm{O}$ afastamento dos cidadãos frente a esses espaços índice diretamente na capacidade de representação social. Todavia, não se trata aqui de um processo caracterizado pelo voluntarismo. Dentre os diversos fatores, cabe destacar a ausência de uma capacitação e a assimetria de poder entre os participantes, sobretudo, referente aos capitais social e cultural que inibem a participação de maneira mais efetiva.

[...] Depende do perfil né, por que tem esse poder, tem. É preciso saber se eu tenho a pessoa, se eu quero qualificar as pessoas para elas entenderem da importância de fazer valer essa influência que tem. Por que o conselho, as pessoas, vem aqui, faz as suas reuniões, 
as suas decisões tomadas pelo conselho. [...] Quando ela não consegue, ela volta a ser discutida de novo e ela ser deliberada. Vai deliberar, quem ganha é quem articula melhor (E5, Segmento Profissionais de Saúde).

Eu acho que num certo ponto sim. Eu acho que não na sua totalidade. É aquilo que eu falei: as pessoas tentam fazer o melhor, mostram os caminhos assim, por que tem muito usuário, então eles sabem da necessidade, das demandas... Eles apresentam isso. Né. Cabe a gente aqui organizar. Mas muitas vezes eu vejo que essa organização, ela não sai daqui. Sai de propostas do governo. E eles fazem normas e regras que muitas vezes a gente não tem a compreensão, por isso que eu falo na capacitação, de que que realmente eles tão falando, entendeu. Até onde aquilo que está escritinho, que eles tão falando é o que, é o que a gente está entendendo (E7, Segmento Profissionais de Saúde).

Os excertos acima reforçam dois pontos relevantes, sendo esses o uso da linguagem como instrumento de inibição e sinalizações quanto ao risco de o conselho se transformar numa forma de legitimação do discurso governamental. E5 reforça que "quem ganha é quem articula melhor", reforçando o uso do poder da linguagem, onde notamos novamente sinais como a falta de habilidade discursiva imantada de uma suposta racionalidade pode se constituir em uma barreira no engajamento na deliberação (MARQUES, 2009). E7, ao apontar que muitas coisas saem de propostas do governo, reforça a preocupação quanto à possibilidade de que este traga para o conselho assuntos de seu interesse e que não seja utilizado como um espaço de canalização e discussão das demandas da população, fazendo assim com que se transforme numa forma de legitimação do discurso governamental.

A falta de recurso é utilizada como argumento para que o poder público não ofereça capacitação aos conselheiros. Esta lacuna, por sua vez, retarda o processo de aprendizagem de parte dos conselheiros acerca de suas funções e perpetua as assimetrias de poder entre os membros, em particular, no que se entende enquanto factibilidade das propostas amparada na racionalidade discursiva. 


\section{CONSIDERAÇÕES FINAIS}

Esse trabalho teve como propósito caracterizar o processo participativo no controle social, no âmbito do Conselho Municipal de Saúde de Juiz de Fora (CMS/JF). Ancorado nas categorias processo de escuta e exercício do papel do conselheiro, concluímos que, embora o Conselho Municipal de Saúde de Juiz de Fora se caracterize como espaço para exercício do controle social, muitos são os pontos críticos frente à participação social, em particular, as tentativas de coerção, a falta de debates profícuos, o tempo escasso para discussões profundas e a existência de barreiras ao processo deliberativo e assimetrias discursivas.

No conselho aqui analisado constatamos a existência de discussões sobre os temas pautados e elevada presença de usuários nas reuniões, bem como uma boa vocalização por parte deste segmento, o que de certa maneira faz atenuar a preocupação quanto à possibilidade de o conselho ser usado como forma de legitimar discursos governamentais. Todavia, são preocupantes as sinalizações de tentativas de coerção, falta de debates profícuos, tempo escasso para discussões profundas e a existência de barreiras ao processo deliberativo, criadas, sobretudo, pelo uso da linguagem.

O processo de escuta é particularmente profícuo quando temas em que há convergência de interesses são debatidos, colocando em xeque a troca de razões, essencial aos processos participativos. Em complemento, são concorrentes ao processo deliberativos pleitos informais que visam persuadir os membros em relação aos pontos de pauta. Muito embora devamos considerar que espaços deliberativos contenham em si contradições e interesses antagônicos, a existência desse tipo de prática deve ser tomada como ameaça ao caráter participativo dos conselhos, pois visa reproduzir as assimetrias e desigualdades existentes nas esferas política e econômica (SHAPIRO, 2002).

Importa, ainda, a assimetria discursiva encontrada, ao constatarmos que as falas se restringem a um pequeno grupo de pessoas, o que, por um lado reforça os achados quanto à participação proforma e, por outro lado, sugere que há, possivelmente, intimidação de novos participantes e uso da linguagem como artifício de constrangimento. Estabelece-se aqui um ponto crítico que vai de encontro ao processo participativo, uma vez que as assimetrias deslocam o conjunto de verdade da razoabilidade das propostas para a posição de fala dos vocalizadores. Reconhecemos ainda a possibilidade de procedimento ad referendum e de decisões influenciadas pelo comportamento grupal como indicações de entraves ao poder decisório do conselho. 
Ademais, constatamos que falta maior engajamento da sociedade e que é necessário que as deliberações se transformem em práticas. Ainda assim, notamos que o conselho é um espaço aberto à escuta e à troca argumentativa, o que nos leva a afirmar que se trata de uma dinâmica de funcionamento aberta ao controle social. Entretanto, assinalamos como entraves a falta de entendimento sobre o próprio papel, condições socioeconômicas dos participantes, interesse político e a falta de comprometimento por parte de alguns membros.

\section{REFERÊNCIAS}

ABERS, R. N.; KECK, M. E. Representando a diversidade: Estado, sociedade e "relações fecundas" nos conselhos gestores. Caderno CRH, v. 21, n. 52, p. 99-112, 2008.

AVRITZER, L. A dinâmica da participação local no Brasil. In: AVRITZER, L. et al. Democracia, desigualdade e políticas públicas no Brasil. Relatório de pesquisa do projeto democracia participativa. Belo Horizonte: FINEP, 2009.

AVRITZER, L. Teoria democrática e a deliberação pública. Lua Nova, n. 50, p. 25-46, 2000.

BAOCCHI, G. Participation, activism, and politics: the Porto Alegre experiment and deliberative democratic theory. Politics \& Society, v. 29, n. 1, p. 43-72, 2001.

BARDIN, L. Análise de conteúdo. Lisboa: Edições 70, 1979.

BORBA, J. O significado político dos conselhos gestores de políticas públicas. In: Encontro de pesquisa em saúde, 2004, Itajaí. Anais... Itajaí: UNIVALI, 2004, p. 33-40, 2004.

BRASIL. Lei Federal nº 8.142 de 28 de dezembro de 1990. Diário Oficial da União, 1990 (b); 28 dez. Disponível em: http://www.planalto.gov.br/ccivil_03/leis/18080.htm. Acesso em: 05 jun. 2015.

BRASIL. Ministério da Saúde. Conselhos de saúde: a responsabilidade do controle social democrático do SUS / Ministério da Saúde, Conselho Nacional de Saúde. Brasília: Ministério da Saúde, 2013.

BURREL, G. Ciência Normal, Paradigmas, Metáforas, Discursos e Geneaologia da Análise. In: CLEGG, S. R; HARDY, C; NORD, W. R. Handbook de Estudos Organizacionais: modelos de análise e novas questões em Estudos Organizacionais. Vol. 1 São Paulo: Atlas, 2007, p. 437-460.

CAMPOS, C. J. G. Método de análise de conteúdo: ferramenta para a análise de dados qualitativos no campo da saúde. Rev Bras Enferm, v. 57, n. 5, p. 611-4, 2004. 
CGU. Controladoria Geral da União. Controle Social: Orientações aos cidadãos para participação na gestão pública e exercício do controle social. Brasília: Secretaria de Prevenção da Corrupção e Informações Estratégicas, 2012.

CHASUKWA, M; CHIWEZA, A. L; CHIKAPA-JAMALI, M. Public participation in local councils in Malawi in the absence of local elected representatives - political eliticism or pluralism? Journal of Asian and African Studies, v. 49, n. 6, p. 705-720, 2014.

CORNWALL, A. Deliberating democracy: scenes from Brazilian Municipal Health Council.

Politics \& Society, v. 36, n. 4, p. 508-531, 2008.

CORREIA, M. V. C. O Controle Social na Política de Saúde Brasileira Frente às Orientações dos Organismos Financeiros Internacionais. Sociedade em Debate, v. 13, n. 2, p. 121-136, 2012 .

CORTES, S. M. V. Construindo a possibilidade da participação dos usuários: conselhos e conferências no Sistema Único de Saúde. Sociologias, Porto Alegre, v. 4, n. 7, p. 18-49, 2002 .

COTTA, R. M. M. et al. O controle social em cena: refletindo sobre a participação popular no contexto dos Conselhos de Saúde. Physis: Revista de Saúde Coletiva, v. 21, n. 3, p. 11211138, 2011.

COTTA, R. M. M.; CAZAL, M. de.; M; MARTINS, P. C. Conselho Municipal de Saúde: (re)pensando a lacuna entre o formato institucional e o espaço de participação social. Ciênc. Saúde Coletiva, v. 15, n. 5, p. 2437-2445, 2010.

CRISTO, S. C. A. de. Controle social em saúde: o caso do Pará. Serviço Social \& Sociedade, n. 109, p. 93-111, 2012.

DIEGUES, G. C. O controle social e participação nas políticas públicas: o caso dos conselhos gestores municipais. NAU Social, v. 4, n. 6, p. 82-99, 2013.

DUARTE, E. B.; MACHADO, M. de F. A. S. O exercício do controle social no âmbito do Conselho Municipal de Saúde de Canindé, CE. Saúde e Sociedade, v. 21, n. 1, p. 126-137, 2012 .

FUKS, M.; PERISSINOTTO, R. M.; RIBEIRO; E. A. Cultura política e desigualdade: o caso dos conselhos municipais de Curitiba. Revista de sociologia e política, v. 21, n. 21, p. 125145, 2003.

GODOY, A. S. Pesquisa qualitativa: tipos fundamentais. Revista de Administração de empresas, v. 35, n. 3, p. 20-29, 1995.

GOULART, M. S. B. Participação e accountability no controle social do orçamento público: o caso do conselho de desenvolvimento regional de Itajaí. 2011. Tese (Doutorado 
em Administração)-Escola de Administração, Universidade Federal da Bahia, Salvador, 2011.

GUIZARDI, F. L.; PINHEIRO, R. Dilemas culturais, sociais e políticos da participação dos movimentos sociais nos Conselhos de Saúde. Ciência \& Saúde Coletiva, v. 11, n. 3, p. 797 $805,2006$.

GURGEL, C.; JUSTEN, A. Controle social e políticas públicas: a experiência dos Conselhos Gestores. Revista de Administração Pública, v. 47, n. 2, p. 357-378, 2013.

HERIAN, M. N; HAMM, J. A; TOMKINS, A. J; PYTLIK ZILLING, L. M. Public

participation, procedural fairness, and evaluations of local governance: the moderating role of uncertainty. Journal of Public Administration Research and Theory, v. 22, p. 815-840, 2012.

JUSTINO FILHO, J. Participação cidadã e controle social nos conselhos municipais de saúde da paraíba: um estudo comparativo. In: III Jornada Internacional de Políticas Públicas, São Luís, 2007, São Luís. Anais... São Luiz: UFMA, 2007.

KLEBA, M. E.; COMERLATTO, D. Vivências de empoderamento no exercício da participação social em conselhos gestores de políticas públicas. Administração Pública e Gestão Social, v. 3, n. 1, p. 23-42, 2011.

LAVALLE, A. G. Participação: valor, utilidade, efeitos e causa. In: PIRES, R. R. (Org)

Efetividade das Instituições Participativas no Brasil: estratégias de Avaliação. Brasília: IPEA, p. 33-42, 2011.

MACHADO, E. H. H; BATISTA, J. V.; KORNIN, T. Governança urbana: estudo sobre conselhos municipais da Região Metropolitana de Curitiba. Governança democrática e poder local: a experiência dos conselhos municipais no Brasil. Rio de Janeiro: Revan, p. 249286, 2004.

MAGALHÃES, T. G.; SOUZA, V. B. O Controle Social no Conselho Municipal do Idoso de Florianópolis: uma análise a partir dos modelos de administração pública, dos modelos de coprodução dos serviços públicos e dos modos de gestão estratégica e social. Revista de Ciências da Administração, v. 1, n. 3, p. 149-164, 2015.

MARENTT, B; FORSTER, R; NOWAK, P. Conceptualizing lay participation in professional health care organizations. Administration \& Society, v. 47, n. 7, p. 827-850, 2015.

MARQUES, A. C. S. As interseções entre o processo comunicativo e a deliberação pública. In: MARQUES, A. C. S. (Org). A deliberação pública e suas dimensões sociais, políticas e comunicativas. Belo Horizonte: Autêntica Editora, p. 11-28, 2009. 
MARTINS, M. F. A distribuição do poder nos Conselhos Municipais de Saúde: o caso dos municípios de Ubá e de Viçosa. Dissertação (Mestrado em Administração)-Universidade Federal de Viçosa, Viçosa, 2010.

MARTINS, S.; CKAGNAZAROFF, I. B.; LAGE; M. L. C. Análise dos Conselhos Gestores de Políticas Públicas à luz dos Relatórios de Fiscalização da Controladoria Geral da União.

Administração Pública e Gestão Social, v. 4, n. 2, p. 221-245, 2012.

MIRANDA, J. M. B.; GUIMARÃES, S. J. Controle social e conselhos locais de saúde em Teresina: limites e possibilidades. Rev FSA, v. 10, n. 3, p. 212-27, 2013.

NELSON, K. L; DABRIS, G. T; DAVIS, T. J. What makes municipal councils effective?: an empirical analysis of how council members perceive their group interactions and processes.

State and Local Government Review, v. 43, n. 3, p. 196-204, 2011.

OLIVEIRA, A. M. C.; IANNI, A. Z.; DALLARI, S. G. Controle social no SUS: discurso, ação e reação. Ciência \& Saúde Coletiva, v. 18, n. 8, p. 2329-2338, 2013.

OLIVEIRA, V. C. S.; PEREIRA, J. R; OLIVEIRA, V. A. R. Os conselhos gestores municipais como instrumentos da democracia deliberativa no Brasil. Cadernos EBAPE.BR, v. 8, n. 3, p. 422-437, 2010.

PAULA, A. P. P. De. Para além dos paradigmas nos Estudos Organizacionais: o Círculo das Matrizes Epistêmicas. Cadernos EBAPE. BR, v. 14, n. 1, p. 24-46, 2016.

PERISSINOTTO, R. M.; FUKS, M; SOUZA, N. R. Participação e processo decisório em alguns conselhos gestores de Curitiba. Revista Paranaense de Desenvolvimento-RPD, n. 105, p. 75-100, 2003.

ROBERT, N. Public deliberation in an Age of Direct Citizen Participation. American

Review of Public Administration, v. 34, n. 4, p. 315-353, 2004.

ROLIM, L. B.; CRUZ, R. de S. B. L. C.; SAMPAIO, K. J. A. de J. Participação popular e o controle social como diretriz do SUS: uma revisão narrativa. Saúde em Debate, v. 37, n. 96, p. 139- 147, 2013.

SABIONI, M; FERREIRA, M. A. M; BRAGA, J. M; ALMEIDA, F. M. Contextos (in)adequados para o engajamento cidadão no controle social. Revista de Administração Pública, v. 50, n. 3, p. 466-500, 2016.

SALIBA, N. A; MOIMAZ, S. A. S; FERREIRA, N. F; COSTÓDIO, L. B. M. Conselho de saúde: conhecimento sobre as ações de saúde. Revista de Administração Pública, v. 43, n. 6, p. 1369-1378, 2009.

SHAPIRO, I. Optimal deliberation? The Journal of Philosophy, v. 10, n. 2, p.196-211, 2002.

REAd | Porto Alegre - Vol. 25 - No 1 - Janeiro / Abril 2019 - p. 179-212 
SHIMIZU, H. E. et al. Representações sociais dos conselheiros municipais acerca do controle social em saúde no SUS. Ciência \& Saúde Coletiva, v. 18, n. 8, p. 2275-2284, 2013. SILVA, C. R.; GOBBI, B. C.; SIMÃO, A. A. O uso da análise de conteúdo como uma ferramenta para a pesquisa qualitativa: descrição e aplicação do método. Organizações Rurais \& Agroindustriais, v. 7, n. 1, p. 70-81, 2005.

SILVA, S. R.; MELlO, M. V. F. A; SILVA, M. P. da; CÁRDENAS, A. M. C. Conselho Estadual de Saúde do Amapá: controle social como forma de empoderamento da sociedade.

PRACS: Revista Eletrônica de Humanidades do Curso de Ciências Sociais da UNIFAP, v. 4, n. 4, p. 59-67, 2012.

SIQUEIRA, R. L., COTTA, R. M. C; SOARES, J. B. Participação social na saúde: saber para promover. Viçosa: Editora UFV, 2015.

SOUZA, C. Construção e consolidação de instituições democráticas: papel do orçamento participativo. São Paulo em Perspectiva, v. 15, n. 4, p. 84-97, 2001.

SOUZA, T. O. de; SILVA, J. M.; NÓBREGA, S. S.; CONSTÂNCIO, J. F. Controle social: um desafio para o conselheiro de saúde. Revista Brasileira de Enfermagem, v. 65, n. 2, p. 215-221, 2012.

TATAGIBA, L. Conselhos gestores de políticas públicas e democracia participativa: aprofundando o debate. Revista de Sociologia e Política, n. 25, p. 209-213, 2005. VAN STRALEN, C. J.; LIMA, A. M. D.; SOBRINHO, D. F.; SARAIVA, L. E. S.; VAN STRALEN, T. B. S.; BELISÁRIO, S. A. Conselhos de Saúde: efetividade do controle social em municípios de Goiás e Mato Grosso do Sul. Ciência \& Saúde Coletiva, v. 11, n. 3, p. 621- 632, 2006.

WENDHAUSEN, A. L. P. Micropoderes no cotidiano de um conselho de saúde. Tese. (Doutorado em Filosofia da Saúde) - Programa de Pós-Graduação em Enfermagem da Universidade Federal de Santa Catarina, Florianópolis, 1999.

WENDHAUSEN, A. L. P; BARBOSA, T. M.; BORBA, M. C. de. Empoderamento e recursos para a participação em conselhos gestores. Saúde e Sociedade, v. 15, n. 3, p. 131144, 2006.

ZAMBON, V. D; OGATA, M. N. Controle social do Sistema Único de Saúde: o que pensam os conselheiros municipais de saúde. Revista Brasileira de Enfermagem., v. 66, n. 6, p. 921-927, 2013. 